\title{
INACTIVATION TEST OF THE LUPUS ERYTHEMATOSUS (L.E.) PLASMA FACTOR
}

\author{
BY
}

GEORGE BENCZE

From the First Department of Medicine, University Medical School, Szeged, Hungary

(Director: Prof. M. Julesz)

The existence of two types of lupus erythematosus (L.E.) plasma factor-transferable and non-transferable-has been suggested by our experiments with lupus erythematosus plasma transfer in vivo (Bencze, Kovács, and Cserháti, 1959; Bencze, Lakatos, and Ludányi, 1960).

Our further experiments in vitro showed differences between the two types of lupus erythematosus factor. These investigations, performed simultaneously with leucocytes from the subject and from other persons have shown that the L.E. factor of the non-transferable type does not produce the L.E. phenomenon, unless the subject's own leucocytes are used; this phenomenon could not be observed at all, or occurred to a much less extent, with leucocytes from other subjects (Bencze and Lakatos, 1960).

The present paper reports a further series of experiments in vitro, having in view the inactivation of the L.E. plasma factor. Earlier observations have shown that the inactivation of the L.E. plasma factor occurs at 59 and $65^{\circ} \mathrm{C}$. respectively (Hargraves, 1949; Haserick, 1950).

\section{Methods}

(1) Plasma obtained from ten patients with L.E.positive systemic lupus erythematosus (S.L.E.) was heated for $30,60,120$, and $240 \mathrm{~min}$. at $+56^{\circ} \mathrm{C}$. $2 \mathrm{ml}$. of each batch of this plasma was added to the subjects' own leucocytes (washed six times in 240-ml. physiological saline) and to leucocytes obtained from normal persons. Subsequently the L.E.-cell test was performed by the rotatory method of Zinkham and Conley (1956).

(2) The usual L.E.-cell examination was done simultaneously in every case as a control test by Zinkham and Conley's rotatory method. Additional L.E.-cell tests were made with the patient's own washed leucocytes not supplemented with plasma, by Zinkham and Conley's rotatory method, to check the proper washing of the leucocytes.

(3) $2 \mathrm{ml}$. transferable plasma collected from each of three S.L.E. patients was kept for 30 and $60 \mathrm{~min}$. respectively at $+65^{\circ} \mathrm{C}$.; they all coagulated within $30 \mathrm{~min}$. The coagulated plasma was broken up with a glass stick and added to normal leucocytes. Subsequently the
L.E.-cell test was done by Zinkham and Conley's rotatory method.

(4) Plasma obtained under sterile conditions from three S.L.E. patients was heated at $+56^{\circ} \mathrm{C}$. for one hour and transfused to dogs in doses of 1 and $2 \mathrm{ml} . / \mathrm{kg}$. body weight respectively, as described in our earlier report (Bencze and Ludányi, 1960).

\section{Results}

Several inactivation tests were performed with plasma obtained from ten different S.L.E. patients, and with the pleural effusion of one such subject. The tests were repeated at least six times with plasma from each patient. The L.E.-cell phenomenon was seen when three batches of L.E. plasma factor of transferable type were used, both with the subject's own leucocytes and leucocytes from other persons, even with plasma kept at $56^{\circ} \mathrm{C}$. for 4 hours In all cases identical amounts of L.E. cells were present, as with plasma not exposed to heat. These three batches of S.L.E. plasma produced the L.E.cell phenomenon, even when heated at $+65^{\circ} \mathrm{C}$. for 30 and $60 \mathrm{~min}$. respectively, when the plasma also coagulated with leucocytes from other persons. One of these patients developed polyserositis. The L.E.-cell phenomenon was also seen when the pleural effusion was added to leucocytes from other persons. This pleural effusion was not inactivated when heated at $56^{\circ} \mathrm{C}$. for 2 hours; the L.E. cells were seen in unchanged amounts when it was added to leucocytes from other persons.

Plasma from the other seven S.L.E. patients was inactivated, however, in $30 \mathrm{~min}$. at $56^{\circ} \mathrm{C}$.; no L.E. cells were seen even when it was added to the subject's own washed leucocytes (Table, opposite, Cases 4 to 10).

Plasma transfer experiments were carried out on dogs with plasma from five of the seven S.L.E. patients; all proved to be non-transferable (Table, Cases 4 to 8). In vitro L.E.-cell investigations, however, showed the presence of the L.E.-cell phenomenon in two patients only with their own leucocyctes (Table, Cases 9 and 10). Using other leucocytes, no L.E. cells, or hardly any, were pro- 
TABLE

TRANSFER OF L.E. CELLS AFTER EXPERIMENTAL INACTIVATION BY HEATING

\begin{tabular}{|c|c|c|c|c|c|c|c|c|c|c|c|c|c|c|c|}
\hline \multicolumn{2}{|l|}{ Experiments } & \multicolumn{12}{|c|}{ In vitro } & \multicolumn{2}{|c|}{$\begin{array}{c}\text { In vivo } \\
\text { Transfer to Dogs }\end{array}$} \\
\hline \multirow{2}{*}{\multicolumn{2}{|c|}{ Source of Leucocytes }} & \multicolumn{7}{|c|}{ Plasma } & \multirow{2}{*}{$\begin{array}{c}\begin{array}{c}\text { Pleural } \\
\text { Effusion }\end{array} \\
\text { Others }\end{array}$} & \multicolumn{2}{|c|}{ Plasma } & \multicolumn{2}{|c|}{$\begin{array}{l}\text { Fresh } \\
\text { Plasma }\end{array}$} & \multirow{2}{*}{$\begin{array}{l}\text { Heated } \\
\text { Plasma }\end{array}$} & \multirow{2}{*}{$\begin{array}{c}\text { Fresh } \\
\text { Plasma }\end{array}$} \\
\hline & & \multicolumn{4}{|c|}{ Subject's Own } & \multicolumn{3}{|c|}{ Others } & & \multicolumn{2}{|c|}{ Others } & Own & Others & & \\
\hline Temperature $\left({ }^{\circ} \mathrm{C}.\right)$ & $\cdots$ & \multicolumn{4}{|c|}{56} & \multicolumn{3}{|c|}{56} & 56 & \multicolumn{2}{|c|}{65} & \multicolumn{2}{|c|}{$\mathrm{Nil}$} & 56 & Nil \\
\hline Heating Time (min.) & $\cdots$ & 30 & 60 & 120 & 240 & 30 & 120 & 240 & 120 & 30 & 60 & \multicolumn{2}{|c|}{ Nil } & 60 & Nil \\
\hline \multirow{10}{*}{ Case No. } & 1 & + & + & + & + & + & + & + & - & + & + & + & + & $\mathbf{T}$ & $\mathbf{T}$ \\
\hline & 2 & + & + & + & + & + & + & + & - & + & + & + & + & $\mathbf{T}$ & $\mathbf{T}$ \\
\hline & 3 & + & + & + & + & + & + & + & + & + & + & + & + & $\mathbf{T}$ & $\mathbf{T}$ \\
\hline & 4 & 0 & 0 & 0 & - & 0 & - & - & - & - & - & + & \pm & - & NT \\
\hline & 5 & 0 & 0 & 0 & - & 0 & - & - & - & - & - & \pm & \pm & - & NT \\
\hline & 6 & 0 & 0 & 0 & - & 0 & - & - & - & - & - & + & \pm & - & NT \\
\hline & 7 & 0 & 0 & 0 & - & 0 & - & - & - & - & - & \pm & \pm & - & NT \\
\hline & 8 & 0 & 0 & 0 & - & 0 & 一 & - & - & - & - & \pm & \pm & - & NT \\
\hline & 9 & 0 & 0 & 0 & - & 0 & - & - & - & - & - & \pm & 0 & - & - \\
\hline & 10 & 0 & 0 & 0 & - & 0 & - & - & - & - & - & + & 0 & - & - \\
\hline
\end{tabular}

duced in the other five patients, even when a large amount of plasma was added.

When we transfused three batches of S.L.E. plasma of the transferable type kept at $56^{\circ} \mathrm{C}$. for $60 \mathrm{~min}$. into dogs, we succeeded in producing L.E. cells in the same way as with plasma not exposed to heat (Table, Cases 1 to 3 ).

\section{Discussion}

Additional differences between the two types of L.E. plasma factor were demonstrated by L.E. plasma factor inactivation tests. We failed to confirm findings reported in the literature concerning the inactivation of the L.E. plasma factor. Our investigations showed that the transferable type of L.E. plasma factor was not inactivated even when heated at $65^{\circ}$ C., whereas the L.E. plasma factor of the non-transferable type was destroyed when heated at $56^{\circ} \mathrm{C}$. for $30 \mathrm{~min}$.

\section{Summary}

In vitro inactivation experiments were carried out with plasma from ten different patients with systemic lupus erythematosus. Three batches of L.E. plasma factor of the transferable type failed to become inactivated, even when heated at $65^{\circ} \mathrm{C}$. for $60 \mathrm{~min}$. Seven batches of L.E. plasma factor of the non-transferable type became inactivated, however, when heated at $56^{\circ} \mathrm{C}$. for $30 \mathrm{~min}$.

\section{REFERENCES}

Bencze, G., Kovács, J., and Cserháti, I. (1959). Brit. med. J., 2, 864. -, Lakatos, L., and Ludányi, M. (1960). Ibid., 1, 1707. -

- and Ludányi, M. (1960). Ann. rheum. Dis., 19, 48

Hargraves, M. M. (1949). Proc. Mayo Clin., 24, 234.

Haserick, J. R. (1950). Arch. Derm. Syph. (Chicago), 61, 889.

Zinkham, W. H. and Conley, C. L.. (1956). Bull. Johns Hopk. Hosp. 98, 102.

\section{Réaction d'inactivation du facteur L.E. du plasma} RÉSUMÉ

On effectua des expériences d'inactivation in vitro avec du plasma provenant de dix malades atteints de lupus érythémateux généralisé. Trois lots du facteur plasmatique L.E. du type transferable n'ont pas pu être inactivés, même à une température de $65^{\circ} \mathrm{C}$. pendant 60 minutes. On est arrivé, cependant, à inactiver sept lots du facteur plasmatique L.E. du type non-transferable en les soumettant à une température de $56^{\circ} \mathrm{C}$. pendant 30 minutes.

\section{Reacción de inactivación del factor L.E. del plasma}

\section{Sumario}

Se llevaron a cabo experimentos de inactivación in vitro con plasma procedente de diez enfermos con lupus eritematoso generalizado. Tres muestras del factor L.E. del plasma del tipo transferible no llegaron a inactivarse, aun siendo sometidas a una temperatura de $65^{\circ}$ C. durante 60 minutos. Siete muestras del factor L.E. del plasma del tipo no transferible resultaron inactivadas sin embargo, cuando se sometieron a una temperatura de $56^{\circ} \mathrm{C}$. durante 30 minutos. 